\title{
Hydrothermal Liquefaction of Spent Coffee Grounds in Water Medium for Bio-oil Production
}

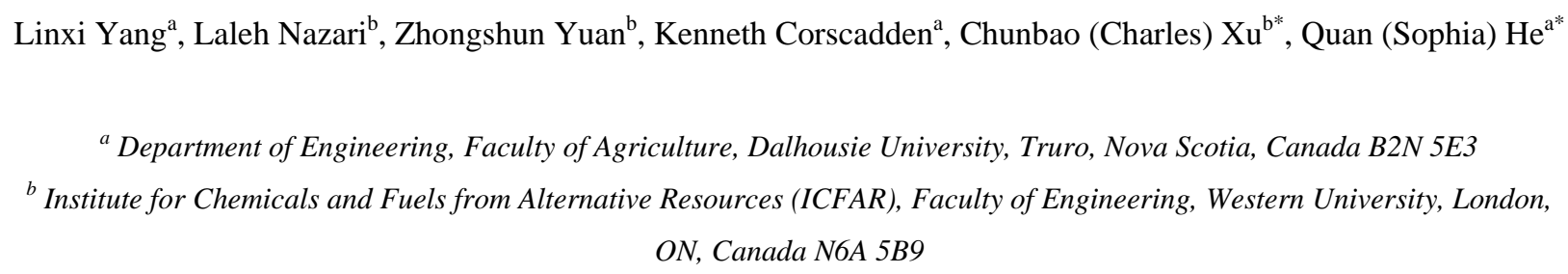

\section{Abstract}

Spent coffee grounds (SCG) were liquefied in hot-compressed water to produce crude bio-oil via hydrothermal liquefaction (HTL) in a $100 \mathrm{~cm}^{3}$ stainless-steel autoclave reactor in $\mathrm{N}_{2}$ atmosphere. We investigated the effects of operating parameters such as retention times (5 min, $10 \mathrm{~min}, 15 \mathrm{~min}, 20 \mathrm{~min}$ and $25 \mathrm{~min})$, reaction temperatures $\left(200{ }^{\circ} \mathrm{C}, 225^{\circ} \mathrm{C}, 250{ }^{\circ} \mathrm{C}, 275^{\circ} \mathrm{C}\right.$ and $\left.300^{\circ} \mathrm{C}\right)$, and water/feedstock mass ratios $(5: 1,10: 1,15: 1$ and 20:1) and initial pressure of process gas (2.0 MPa and 0.5 MPa) on the yield and properties of the resulting crude bio-oil. The highest yield of the crude bio-oil (47.3\% mass fraction) was obtained at conditions of $275{ }^{\circ} \mathrm{C}, 10 \mathrm{~min}$ retention time and water/feedstock mass ratio of 20:1 with an initial pressure of 2.0 MPa. The elemental analysis of the produced crude bio-oil revealed that the oil product had a higher heating value (HHV) of $31.0 \mathrm{MJ} \cdot \mathrm{kg}^{-1}$, much higher than that of the raw material $\left(20.2 \mathrm{MJ} \cdot \mathrm{kg}^{-1}\right)$. GC-MS and FT-IR measurements showed that the main volatile compounds in the crude bio-oil were long chain aliphatic acids and esters.

Keywords: hydrothermal liquefaction; spent coffee grounds; hot-compressed water; crude biooil

Corresponding authors: quan.he@dal.ca and cxu6@uwo.ca 


\section{Introduction}

The inherent conflict between the increase of global energy demand and the depletion of fossil fuel reserves, along with the environmental concerns caused by the extensive use of fossil fuels, has necessarily called for sustainable energy alternatives [1]. Using biomass for liquid biofuels production has sparked the interest worldwide due to its abundance, renewability and carbon neutrality [2]. However, today, the major viable commercial options for producing liquid biofuels use edible crops (vegetable oils for biodiesel and corn/sugarcane for bioethanol), which has negative impacts on food and feed supplies [2, 3]. Research efforts are, therefore, reorientated to use the biological waste such as agricultural and forest residues, animal manure, food processing waste and municipal waste [4-10]. Utilizing waste streams for biofuels production also has additionally environmental benefits, including reducing the local pollution, decreasing greenhouse gas emissions, and lessening the burden on landfills.

Coffee is one of the most popular beverages and widely consumed in America, Japan and Europe $[11,12]$. According to the coffee trade record from the International Coffee Organization [13], the global coffee production has increased by $6 \%$ since 2010, and the total coffee production in 2014 was 142 million bags, equalling 9.6 million tonnes. The amount of spent coffee grounds (SCG), the solid residues obtained from coffee brewing, therefore increases accordingly. Despite such biomass residues are generated in large quantities each year, they are mostly underutilized, being disposed in landfills or small amounts used for composting [14]. However, the complex organic substances (e.g., caffeine, tannins and polyphenols) left in the coffee residue were found to have adverse impacts on land and the environment [11]. Some industries attempted to process SCG into coffee logs or pellets for heating and electricity generation, while its combustion generated particulate matter and hazardous gases, especially high nitrogen oxidants in emissions, compared to wood pellets or briquettes. This dramatically limits the direct use of SCG as solid fuels $[15,16]$. New interests are recently developed to use SCG for liquid biofuels production. Kondamudi et al. [12] extracted coffee oil from SCG for biodiesel production. However, the average oil content in SCG is fairly low, only 10-15\% mass fraction, and the necessary solvent extraction makes this option economically unfavorable. Mussatto et al. [17] evaluated the feasibility of producing bioethanol from SCG through fermentation using three different yeasts, while the ethanol production yield was only $26.0 \%$ mass fraction. Other researchers [18-20] used a fast pyrolysis process to convert SCG into the 
bio-oil. The results were very promising, with an oil yield as high as $54.9 \%$ mass fraction. Unfortunately, SCG has a fairly high moisture content (50- $60 \%$ mass fraction) [12], and thus a pre-drying process is required before SCG is fed to a pyrolysis system. This leads to a large energy consumption and decreases the overall economic viability. Moreover, the quality of the pyrolysis bio-oil is not satisfactory. A relatively high oxygen (35.2-59.5\% mass fraction) resulted in lower HHVs in a range of $17 \mathrm{MJ} \cdot \mathrm{kg}^{-1}$ to $23 \mathrm{MJ} \cdot \mathrm{kg}^{-1}$, depending on the composition of feedstock and pyrolysis conditions. Therefore, it is essential to explore other pathways to utilize this waste stream effectively, efficiently and economically.

Hydrothermal liquefaction (HTL) is an emerging technology that is able to convert wet biomass (especially waste materials) to the oil (referred to as bio-oil or biocrude), aqueous, gaseous and solid products at high pressures (5-22 MPa) and moderate temperatures (250-380 ${ }^{\circ} \mathrm{C}$ ) in sub-/supercritical water medium [21, 22]. HTL is advantageous over other thermochemical conversion technologies such as fast pyrolysis and gasification. It is carried out at lower temperatures; more importantly, it accepts wet biomass, and thus obviates an energyintensive pre-drying process. Also, the bio-oil obtained from the liquefaction process is hydrophobic, typically has a lower oxygen and water content, giving much higher HHV (25-35 $\mathrm{MJ} \cdot \mathrm{kg}^{-1}$ ) compared to those of the fast pyrolysis bio-oil (14-20 MJ. $\left.\mathrm{kg}^{-1}\right)$. The HTL crude bio-oil can be mixed with other fuels and used for combustion or be further upgraded to high quality hydrocarbon liquid fuels such as gasoline and diesel [22-26].

Many researchers have been focusing on the bio-oil production via the HTL process from a wide variety of biomass, including woody biomass, mainly forest residues [27-30], agricultural waste such as barley straw, corn stalk, corncob and rice husk [31-34], animal manure [35-37], municipal solid waste [38-40] and most recently microalgae [41-48]. Through these studies, it was found that the yield and quality of the bio-oil resulting from the HTL process were highly associated with the operating parameters such as the reaction temperature, retention time, ratio of feedstock and solvent, etc., as reviewed by Akhtar and Amin [49] as well as the experimental results reported in the literature [27-48]. The commonly used temperature range is from $250{ }^{\circ} \mathrm{C}$ to $400{ }^{\circ} \mathrm{C}$; and usually around $300{ }^{\circ} \mathrm{C}$, the maximum bio-oil yield was obtained. At a low temperature, an incomplete decomposition of biomass gives a relatively high solid residues yield and a low bio-oil yield. With an increase in the liquefaction temperature, the yield of bio-oil increases while the solid residue decreases. However, at the temperature higher than $300^{\circ} \mathrm{C}$, for 
most feedstocks, a decreased bio-oil yield and increased gas fraction yield are observed due to a secondary decomposition of the bio-oil and Bourdard gas reactions. However, the solid residue yield may also increase, being caused by the re-polymerization of the bio-oil components and/or re-combination of high-concentration free radicals to form bio-char. Retention time is another key factor influencing the bio-oil production and the overall biomass conversion. Generally, a short retention time (10-30 $\mathrm{min})$ is preferred, giving a relatively high bio-oil yield. The ratio of feedstock and solvent also plays an important role in the biomass liquefaction process. It was observed that a low ratio of feedstock and solvent led to a high bio-oil yield, however it was not economically favorable. In contrast, some researchers also found that a higher biomass concentration might promote the dehydration/polymerisation of the intermediates products, which resulted in an increase of the bio-oil yield. Despite enormous studies conducted and significant progress made, the underlying mechanism of the effects of operating parameters on HTL process was so far not fully understood. The optimization of reaction conditions and knowledge of the interaction of operating parameters have to be obtained by experiments.

In addition to operating parameters, the nature of biomass, i.e., different components of cellulose, lignin, protein and fat, significantly impacts the yield and chemical composition of the HTL products. To date, most of studies examined the lignocellulose-based feedstock (e.g., forest residues, agricultural wastes), which contains a relatively high content of lignin while low contents of lipid and protein [27-30, 50]. The HHVs of the HTL bio-oils obtained from the lignocellulose biomass (without using any catalysts and organic solvents) are in the range of 30$36 \mathrm{MJ} \cdot \mathrm{kg}^{-1}$, and the oil yields are relatively low (20\% to $36 \%$ mass fraction). These studies indicated that a high content of lignin in feedstock was not desirable for the bio-oil production. Recently, it was observed that high lipid and protein contents in feedstock benefited the yield and the quality of the bio-oil $[41-48,51,52]$.

A thorough literature review encouraged us to explore the feasibility of converting the spent coffee grounds (SCG) to bio-oil via HTL. SCG has higher contents of lipid $(\approx 15 \%)$ and protein $(\approx 17.4 \%)$, while a lower content of lignin $(\approx 23.9 \%)$, compared to the lignocellulose biomass $[11,12$, 53]. It might be a promising feedstock for the bio-oil production using the HTL technology. More attractively, the size of SCG is in the range of 200-300 $\mu \mathrm{m}$ [19], which makes it suitable for being directly fed to the HTL reactor without a prior engery-intensive grinding process. 
In this study, SCG was liquefied in hot-compressed water in $\mathrm{N}_{2}$ atmosphere. Effects of the retention time (varied from $5 \mathrm{~min}$ to $30 \mathrm{~min}$ ), reaction temperature (varied from $200{ }^{\circ} \mathrm{C}$ to $300{ }^{\circ} \mathrm{C}$ ), water/feedstock mass ratio (varied from 5:1 to $20: 1$ ) and initial pressure $(0.5 \mathrm{MPa}$ and 2.0 $\mathrm{MPa}$ ) on the yield of product fractions were investigated, with an expectation of maximizing the oil yield. The properties of the resulting bio-oil (e.g., elemental composition, higher heating value, and chemical composition) were characterized. To the best our knowledge, this is the first to examine SCG as a feedstock for the bio-oil production via a hydrothermal liquefaction process.

\section{Experimental}

\subsection{Materials}

The wet SCG for this study were collected after coffee beans (Coffea arabica) brewing from Tim Hortons, London, Canada, and were first air-dried at room temperature over several days, and then were oven dried at $105{ }^{\circ} \mathrm{C}$. The dried SCG were kept in sealed bags and stored in refrigerator at $4{ }^{\circ} \mathrm{C}$. For each experiment, the required amount of raw material was dried further in an oven at $105{ }^{\circ} \mathrm{C}$ overnight. The proximate and ultimate analyses of dried SCG are respectively listed below: $82.3 \%$ volatiles, $1.4 \%$ ash, $4.0 \%$ moisture and $50.4 \% \mathrm{C}, 7.2 \% \mathrm{H}$, $2.1 \% \mathrm{~N}$, and $40.3 \% \mathrm{O}$ (calculated by difference). The solvents used were distilled water and reagent grade acetone, purchased from Caledon laboratories Ltd., which was used as received.

\subsection{Hydrothermal liquefaction procedure}

The experiments were carried out in a $100 \mathrm{~cm}^{3}$ stainless-steel autoclave (Parr Instrument, 5513) equipped with a stirrer. In a typical run, 2.5-10 g dried SCG were weighed and loaded into the reactor, followed by the addition of certain amount of distilled water with desired water/feedstock mass ratios 5:1, 10:1, 15:1 and 20:1, respectively. The occupation of reactor volume was maintained between $50 \mathrm{~cm}^{3}$ to $60 \mathrm{~cm}^{3}$. The reactor with the suspension of feedstock and distilled water was oscillated in an ultrasonic bath for 3 min to ensure the suspension was well-mixed. The reactor was then sealed and the air inside the reactor was displaced by purging nitrogen several times. The reactor was pressurized to 0.5 or $2.0 \mathrm{MPa}$ with high purity nitrogen. The stirring speed was set at $4.5 \mathrm{~Hz}$, the reaction mixture was then ramped up to the pre-set 
temperature $\left(200{ }^{\circ} \mathrm{C}, 225^{\circ} \mathrm{C}, 250{ }^{\circ} \mathrm{C}, 275^{\circ} \mathrm{C}\right.$ and $\left.300^{\circ} \mathrm{C}\right)$, at a heating rate of $10^{\circ} \mathrm{C} \cdot \mathrm{min}^{-1}$. After the system reached the desired temperature, the reactor was kept at the temperature for a specified retention time (between $5 \mathrm{~min}$ to $30 \mathrm{~min}$ ).

\subsection{Separation of reaction products}

Once the reaction was completed, the reactor was cooled down to room temperature in an ice water bath, and the gaseous product (GP) inside the reactor was collected with a pre-vacuumed gas bag. In each run, the gas bag was injected with $120 \mathrm{~cm}^{3}$ air as an internal standard for MicroGC analysis. The reactor was opened. Solid and water phase mixture were carefully collected, rinsed by $30 \mathrm{~cm}^{3}$ distilled water and separated by vacuum filtration through a pre-weighed filter paper. The filtrate was designated as water soluble product (WSP), containing dissolved organic compounds. The reactor, the stirrer and the solid remained on the filter paper was further rinsed using acetone several times to fully recover oil phase. The resulting suspensions were filtered through the same filter paper. The solid residue (SR) product and filter paper was dried in the oven at $105{ }^{\circ} \mathrm{C}$ overnight and then weighed to determine the mass of SR. Acetone in the filtrate was then removed by rotary evaporator under vacuum at $55^{\circ} \mathrm{C}$, resulting in the liquid product referred to as "crude bio-oil". Yields of the crude bio-oil, SR and GP, all were expressed as percentage in a mass basis, and were calculated by the ratio of the mass of each product to the mass of SCG (dry basis) loaded to the reactor. The yields of WSP were determined by difference (100\% - crude bio-oil yield - SR yield - GP yield). The biomass conversion rate was calculated by (100\% - SR yield). All experiments were conducted in triplicate in order to ensure the repeatability of the results and to minimize the experimental errors $(<5 \%)$. In all figures, the mean values of the data along with the corresponding error bars (for the yields of crude bio-oil, SR, WSP and GP) were presented.

\subsection{Product characterization}

The composition of gaseous products was analyzed using GC-TCD (Agilent Micro-GC 3000) and the system employed in this study was able to analyze the gas species, including $\mathrm{H}_{2}, \mathrm{~N}_{2}, \mathrm{O}_{2}$, $\mathrm{CO}_{2}, \mathrm{CO}, \mathrm{CH}_{4}, \mathrm{C}_{2} \mathrm{H}_{4}, \mathrm{C}_{2} \mathrm{H}_{6}, \mathrm{C}_{3} \mathrm{H}_{8}$, and $\mathrm{C}_{3} \mathrm{H}_{6}$. The volatile compositions of the crude bio-oils were analyzed by a Gas Chromatograph-Mass Spectrometer (GC-MS, Agilent Technologies, 5977A MSD) with a SHRXI -5MS column $(30 \mathrm{~m} \times 250 \mu \mathrm{m} \times 0.25 \mu \mathrm{m})$ and a temperature 
program as follows: $60{ }^{\circ} \mathrm{C}$ held for $2 \mathrm{~min}$, then heated to $320{ }^{\circ} \mathrm{C}$ at a rate of $20^{\circ} \mathrm{C} \cdot \mathrm{min}^{-1}$, held for 5 min. Compounds in the produced crude bio-oils were identified by means of the NIST database 2011. The functional groups of the crude bio-oils were confirmed by PerkinElmer FTIR spectrometer within the wavelength range of $4000-550 \mathrm{~cm}^{-1}$. The relative molecular mass and their distribution of crude bio-oils were analyzed by Waters Breeze gel permeation chromatography (GPC). The analysis was conducted on a 1525 Binary High Performance Liquid Chromatography (HPLC), equipped with a UV detector at a wavelength of $270 \mathrm{~nm}$ and a Waters Styrange HR 1 column. The column temperature was $40{ }^{\circ} \mathrm{C}$, and the mobile phase was tetrahydrofuran (THF), the flow rate of which was $1 \mathrm{~cm}^{3} \cdot \mathrm{min}^{-1}$. Linear polystyrene standard was used for calibrating the relative molecular mass of the samples. The $\mathrm{pH}$ values were measured by a $\mathrm{pH}$ meter (SympHony, H10P, VWP) and the water contents of the crude bio-oil were determined in accordance with American Society for Testing and Materials (ASTM) standard. Elemental composition ( $\mathrm{C}, \mathrm{H}$ and $\mathrm{N}$ ) of SCG and crude bio-oil were analyzed using an elemental analyzer (Flash EA 1112 analyzer). The composition of oxygen $(\mathrm{O})$ was calculated by difference and the sulphur content (S) in samples was assumed negligible. The Higher Heating Values (HHV) of SCG, and crude bio-oils were calculated according to Eq. (1) the Dulong formula [34]:

$$
\mathrm{HHV}\left(\mathrm{MJ} \cdot \mathrm{kg}^{-1}\right)=0.3383 \mathrm{C}+1.442(\mathrm{H}-(\mathrm{O} / 8))
$$

Where $\mathrm{C}, \mathrm{H}$ and $\mathrm{O}$ are mass percentages of carbon, hydrogen, and oxygen in the crude bio-oil, respectively, obtained from the elemental analysis.

The energy recovery expressed in \% of the crude bio-oil was calculated by the Eq. (2) [44]:

Energy recovery $(\%)=\frac{\mathrm{HHV} \text { of crude bio-oil } \times \text { mass of crude bio-oil }}{\mathrm{HHV} \text { of SCG } \times \text { mass of SCG }} \times 100$

Where HHV is the higher heating value, calculated by Eq. (1).

\section{Results and Discussion}

\subsection{Effects of retention time}

Retention time in a HTL process impacts the product yield and distribution. It is generally believed that a shorter residence time is preferred to degrade biomass effectively as the rate of decomposition and hydrolysis of biomass is fairly fast in the HTL process [2, 49,54].

In this study, SCG liquefaction was examined by varying retention times from 5 min to 30 min in a hot-compressed water medium and the results are illustrated in Fig. 1. As the gas yields 
221 were very low (less than 1\% mass fraction) under these experimental conditions, they were 222 lumped with the water soluble product as WPS + gas yields. As shown in Fig. 1, at a constant 223 temperature of $300{ }^{\circ} \mathrm{C}$ and a water/feedstock mass ratio of 5:1, the crude bio-oil yield reached 224 the highest point of $31.63 \%$ at a retention time of $10 \mathrm{~min}$, then started decreasing to $22.68 \%$ as 225 the retention time was increased to $30 \mathrm{~min}$. The results indicated that $10 \mathrm{~min}$ was sufficient to 226 break down biomass and achieve the highest yield of crude bio-oil. When a longer retention time 227 was applied, the crude bio-oil would be decomposed into smaller and lighter products and gases, as evidenced by a decrease in the average relative molecular mass of crude bio-oil from 479 $\mathrm{g} \cdot \mathrm{mol}^{-1}$ to $433 \mathrm{~g} \cdot \mathrm{mol}^{-1}$ when the retention time increased from $10 \mathrm{~min}$ to $30 \mathrm{~min}$. This speculation can be further supported by the observation that yields of WSP and gases showed a continuously increasing trend from $44.91 \%$ to $52.62 \%$ when the retention time changed from 10 min to 30 min. This indicated that most of the organic matters in the raw material were converted into the crude bio-oil, WSP and GP within $10 \mathrm{~min}$. In terms of SR, the yield remained constant at about $24.03 \%$ from $5 \mathrm{~min}$ to $25 \mathrm{~min}$, and only showed a slight increase at a longer retention time (30 min). This might be caused by the re-polymerization of the crude bio-oil compounds into the solid residues, resulting in the decrease yield of the crude bio-oil. Our experimental results showed that a long retention time impacted the yield of SR less significantly, however favored the formation of WSP, leading to a lower yield of the crude bio-oil product. Similar results were observed in the reported studies from other researchers $[49,55]$.

Under our experimental scope, the highest yield of crude bio-oil of $31.63 \%$ was achieved with a reaction time of $10 \mathrm{~min}$. Therefore, the retention time of $10 \mathrm{~min}$ was used in the following work to investigate the effects of the temperature, water/feedstock mass ratio and initial pressure on the SCG liquefaction.

[Here] Fig. 1. Yields of bio-oil, solid residue, WSP, and gas under different retention time (temperature of $300{ }^{\circ} \mathrm{C}$ and water/feedstock mass ratio of 5:1 with $2.0 \mathrm{MPa}$ initial $\mathrm{N}_{2}$ pressure).

\subsection{Effect of temperature}

Compared to the effects of the retention time, the influence of the reaction temperature on SCG liquefaction was more significant. 
Fig. 2 illustrates the effects of the reaction temperature ranging from $200{ }^{\circ} \mathrm{C}$ to $300{ }^{\circ} \mathrm{C}$ on the yields of the crude bio-oil, SR, WSP and GP products resulting from the SCG liquefaction in 10 min with a water/feedstock mass ratio of 5:1. As seen from Fig. 2, the crude bio-oil yields increased continuously from $16.58 \%$ to $35.29 \%$ as the temperature increased from $200{ }^{\circ} \mathrm{C}$ to $275^{\circ} \mathrm{C}$, however it started dropping remarkably to $31.63 \%$ when the temperature was further increased to $300{ }^{\circ} \mathrm{C}$. The yield of SR decreased consistently from $42.33 \%$ to $23.53 \%$ as the temperature increased. The results indicated that, at a low temperature, the decomposition of biomass was incomplete and left a large amount of unreacted biomass which may supress the crude bio-oil formation. The rise in temperature was able to accelerate the decomposition of the feedstock and benefited the crude bio-oil formation; however, a further increase in temperature, higher than $275^{\circ} \mathrm{C}$ in our experiments, would break down the previously formed crude biooil/intermediates to smaller molecules (WSP and GP), and thus led to a decrease in the crude bio-oil yield. GPC analyses showed that the relative molecular mass of the crude bio-oil decreased remarkably from $769 \mathrm{~g} \cdot \mathrm{mol}^{-1}$ to $479 \mathrm{~g} \cdot \mathrm{mol}^{-1}$ with increasing temperature, suggesting that the HTL reaction was a thermally-controlled process and the high temperature would decompose biomass to products with a low relative molecular mass. The reducing yield of the SR suggested an increase of the overall biomass conversion when increasing the temperature from $200{ }^{\circ} \mathrm{C}$ to $300{ }^{\circ} \mathrm{C}$. As for the yield of the WSP and GP, they showed an initially decreasing and then increasing trend in the temperature range of $200{ }^{\circ} \mathrm{C}$ to $300{ }^{\circ} \mathrm{C}$. At a lower temperature, volatile compounds were readily evaporated and partially dissolved in the water medium, giving a relatively high yield of WSP and GP. As the temperature increased, these components may react with the decomposed biomass to form oil compounds through a series of reactions such as condensation, polymerization and depolymerisation etc., thus the fraction of WPS product decreased. When temperature was higher than $275^{\circ} \mathrm{C}$, the oil product was secondarily cracked into lighter products and resulted in an increasing in the WSP yield. In addition, the Bourdar gas reaction might become more active at the higher temperatures and lead to the formation of more gaseous products and less crude bio-oil [56]. These results are consistent with the research reported in the literature [29, 31, 33, 40, and 49]. For example, Akhtar and Amin [49] stated that the temperature was one of the most important factors influencing the biomass liquefaction and a moderate temperature (from $250{ }^{\circ} \mathrm{C}$ to $300^{\circ} \mathrm{C}$ ) generally yielded a higher amount of crude bio-oil. 
290

291

292

293

$\mathrm{Xu}$ and Lancaster [40] also suggested that the temperature was the most critical parameter in the overall biomass conversion in the HTL process.

Under our experimental conditions, $275^{\circ} \mathrm{C}$ was identified to be the most suitable temperature for the SCG liquefaction, producing the highest bio-oil yield of $35.29 \%$ in the hot-compressed water with the retention time of $10 \mathrm{~min}$ and the water/feedstock mass ratio of 5:1.

[Here] Fig. 2. Yields of bio-oil, solid residue, WSP, and gas from the liquefaction at various reaction temperatures (retention time of $10 \mathrm{~min}$ and water/feedstock mass ratio of 5:1 with 2.0 $\mathrm{MPa}$ initial $\mathrm{N}_{2}$ pressure).

\subsection{Effect of water/feedstock mass ratio}

The effects of different water/feedstock mass ratios $(5: 1,10: 1,15: 1$ and 20:1) were also investigated in HTL of SCG under the reaction condition of $275^{\circ} \mathrm{C}, 10$ min with $2.0 \mathrm{MPa}$ initial $\mathrm{N}_{2}$ pressure. Fig. 3 clearly illustrated that larger mass ratios of water to SCG had positive impacts on the crude bio-oil yield and total biomass conversion rate. As the mass ratio of water/SCG increased from 5:1 to 20:1, the corresponding crude bio-oil yield increased from $35.29 \%$ to $47.28 \%$ and the solid residue reduced from $31.34 \%$ to $17.33 \%$.

Similar results were also observed in other studies showing that higher mass ratio of water/feedstock resulted in higher yield of crude bio-oil and lower solid residues [27, 28, 33, 34, and 36]. A generally accepted explanation for this observation is that a lower oil yield at a lower solvent/biomass ratio was caused by an insufficient mixing of reactants due to a limited amount of water. This would lead to unfavourable heat/mass transfer conditions inside the reactor, and hence, slow down the liquefaction process and solvolysis reaction, and finally generate less biooil and more solid residues [41]. On the contrary, higher water concentration would prevail throughout the whole process, which might accelerate the sovolysis, hydration, and hydrolysis reaction of the raw material and finally result in an increased yield of crude bio-oil and also achieved a higher biomass conversion [27, 40]. However, high mass ratio of water/feedstock, implying a low process capacity, is economically unfavorable. In real application, a good balance should be struck taking oil yield/batch, overall processing capacity and operating costs into consideration. 
Based on above experimental results obtained in our work, the highest crude bio-oil yield of $47.28 \%$ was achieved under the reaction condition of $275{ }^{\circ} \mathrm{C}, 10 \mathrm{~min}$ and $20: 1$ water/feedstock mass ratio, when the initial $\mathrm{N}_{2}$ pressure was $2.0 \mathrm{MPa}$.

[Here] Fig. 3. Yields of bio-oil, solid residue, WSP, and gas from the liquefaction with various water/feedstock mass ratios (retention time of $10 \mathrm{~min}$ and temperature of $275^{\circ} \mathrm{C}$ with $2.0 \mathrm{MPa}$ initial $\mathrm{N}_{2}$ pressure).

\subsection{Effect of $\mathrm{N}_{2}$ initial pressure}

Nitrogen was used as a process gas in this study and was believed to be inactive in the HTL of SCG, considering the reaction temperature, retention time and water/feedstock mass ratio involved. When lowered the initial pressure from 2.0 $\mathrm{MPa}$ to $0.5 \mathrm{MPa}$ under the reaction condition of $275{ }^{\circ} \mathrm{C}, 10 \mathrm{~min}$ and $20: 1$ of water/feedstock mass ratio, the yields of crude bio-oil, WSP + gas and SR were $44.33 \%, 38.08 \%$ and $17.59 \%$, respectively. The standard deviations of the product yields between 0.5 and 2.0 MPa initial pressure were all below $2 \%$, indicating that the change of initial pressure had very little impact on the products distribution. The final pressures after heating under both conditions were close to $6.0 \mathrm{MPa}$, also suggesting the little effect of initial pressure on the HTL of SCG. The possible reason could be that more water in the reactor evaporated at low temperature, which led to the increase of the final pressure. However, it took a longer time for the reactor to reach the desired temperature when decreased the initial pressure. This also agrees with the results of studies from $\mathrm{Yu}$, et al. [57] and Goudriaan and Peferoen [26], in which the elevated initial pressure had no effect on HTL of biomass but only prevent the water from boiling so that the reaction will take place in single-phase and avoid large heat supply and longer heating time for maintaining the temperature of the system.

\subsection{Bio-oil characterizations}

In addition to the yield, the properties of the resulting bio-oil are also important in this work. The crude bio-oil obtained under conditions of the reaction temperature $275{ }^{\circ} \mathrm{C}$, reaction time of $10 \mathrm{~min}$, water/feedstock mass ratio of $20: 1$ and $2.0 \mathrm{MPa}$ of initial $\mathrm{N}_{2}$ pressure, was characterized as a representative and reported in the following sections. 


\subsubsection{Properties of the resulting crude bio-oil}

The crude bio-oil obtained from the HTL process of SCG were coffee-brown, viscous and possessed a coffee-aromatic odor with a water content of $2.1 \%$ and $\mathrm{pH}$ of 4.8. The elemental composition $(\mathrm{C}, \mathrm{H}$ and $\mathrm{N}$ ) of the raw material and the representative crude bio-oil product was determined by an elemental analyzer and presented in Table 1. The results showed that the SCG crude bio-oil contained a higher content of carbon and a less oxygen content than those of the raw materials. The oxygen content of SCG was greatly reduced from approximately $40 \%$ down to $19 \%$ mass fraction, and the $\mathrm{O} / \mathrm{C}$ molar ratio dropped from 0.6 to 0.2 . This was expected since the oxygen was removed in the form of $\mathrm{CO}$ or $\mathrm{CO}_{2}$ through decarbonylation reaction and decarboxylation reaction, respectively, in the process of liquefaction. This resulted in a significant increase in the higher heating value, as presented in Table 1, in which the HHV of the bio-oil was $31.0 \mathrm{MJ} \cdot \mathrm{kg}^{-1}$, much higher than that of SCG $\left(20.2 \mathrm{MJ} \cdot \mathrm{kg}^{-1}\right)$. Additionally, the energy recovery of the resulting oil at such conditions was fairly high with a value of $72.6 \%$, indicating that a large percentage of the energy in the feedstock was recovered in the oil phase. It was thus concluded that HTL is a suitable technology to convert SCG to a more energy-rich biooil with the potential to be used as a renewable energy source.

[Here] Table 1. Elemental analyses of SCG and crude bio-oil under the reaction condition of 275 ${ }^{\circ} \mathrm{C}, 10 \mathrm{~min}, 20: 1$ water/feedstock mass ratio with 2.0 $\mathrm{MPa}$ initial $\mathrm{N}_{2}$ pressure.

\subsubsection{GC-MS}

The chemical composition of the crude bio-oil derived from SCG was further identified by a GC-MS analysis. Table 2 illustrates the major compounds in the SCG-derived crude bio-oil under the liquefaction condition of $275^{\circ} \mathrm{C}, 10 \mathrm{~min}$ and water/feedstock mass ratio of 20:1 with 2.0 $\mathrm{MPa}$ initial $\mathrm{N}_{2}$ pressure. The area $\%$ was defined by the percentage of the chromatographic area of each compound out of the total area. They showed the relative concentration of each compound in the derived crude bio-oil. It should be noted that only volatile compounds in the crude bio-oil passing through the GC column were identified and reported here. According to the results given by GC-MS, the main volatile chemical components in the crude bio-oil were $\mathrm{C}_{16}-$ $\mathrm{C}_{18}$ aliphatic acids with long carbon chain hydrocarbons (96\%), including $48.15 \%$ of $\mathrm{n}$ hexadecanoic acid, $32.99 \%$ of 9,12-octadecadienoic acid (Z,Z)-, $15.46 \%$ of octadecanoic acid 
and a small amount of $\mathrm{C}_{20}$ aliphatic acids (eicosanoic acid). They were mainly derived from the decomposition and re-polymerization of lipids in the raw materials. Little amounts of $\mathrm{C}_{25}$ esters were also detected, which were from the carbohydrates in the feedstock. The similar carboxylic acids components of the crude bio-oil were also observed in the bio-oils derived from other lipids/protein containing feedstock, such as Litsea cubeba seed and swine manure [36, 51].

[Here] Table 2 Major compounds in the crude bio-oil derived from SCG liquefaction (temperature of $275^{\circ} \mathrm{C}$, retention time of $10 \mathrm{~min}$ and water/feedstock mass ratio of 20:1 with 2.0 $\mathrm{MPa}$ initial $\mathrm{N}_{2}$ pressure).

\subsubsection{FT-IR Analysis}

FTIR spectra for SCG and the crude bio-oil derived from SCG liquefaction under the liquefaction conditions of $275^{\circ} \mathrm{C}, 10 \mathrm{~min}$, water/feedstock mass ratio of 20:1 with $2.0 \mathrm{MPa}$ initial $\mathrm{N}_{2}$ pressure are illustrated in Fig. . Similar functional groups presented in both the SCG and crude bio-oil. A broad absorbance was displayed at around $3400 \mathrm{~cm}^{-1}$ for the raw material, which indicated a high content of carbohydrates and proteins [51]. The crude bio-oil showed a weaker absorbance at the wavenumber of $3400 \mathrm{~cm}^{-1}$, suggesting that both carbohydrates and proteins were decomposed in HTL process. Absorption between $2700 \mathrm{~cm}^{-1}$ and $3000 \mathrm{~cm}^{-1}$ was ascribed to $\mathrm{O}-\mathrm{H}$ stretching vibration and the bond of $\mathrm{O}-\mathrm{H}$, mainly from long-chain carboxylic acids in the bio-oil. The absorption peaks between $1650-1750 \mathrm{~cm}^{-1}$ were attributed to the $\mathrm{C}=\mathrm{O}$ stretching from carboxylic acids and ester groups in the crude bio-oil. A weaker absorbance in this wavenumber range was also observed for the raw material, indicating that more carboxylic acid groups were formed during HTL process. The bands from $1350 \mathrm{~cm}^{-1}$ to $1470 \mathrm{~cm}^{-1}$ were ascribed to $\mathrm{C}-\mathrm{H}$ bending, which indicated alkyl groups in the obtained oil. Absorption between $1020 \mathrm{~cm}^{-1}$ and $1340 \mathrm{~cm}^{-1}$ was attributed to $\mathrm{C}-\mathrm{N}$ bands, most likely showing the presence of amines groups which might be in non-volatile compounds thus were not detected by GC-MS. Meanwhile, the absorption profiles between $670 \mathrm{~cm}^{-1}$ and $870 \mathrm{~cm}^{-1}$ implied the presence of phenyl rings and substituted phenyl rings [27]. The bond at $1050 \mathrm{~cm}^{-1}$ only appeared in the 
absorption profile of SCG, which could be $\mathrm{C}-\mathrm{O}$ connected with hydroxyl groups and were dehydrated after liquefaction.

[Here] Fig. 4. FTIR spectrum of SCG and the crude bio-oil derived from SCG liquefaction (temperature of $275^{\circ} \mathrm{C}$, retention time of $10 \mathrm{~min}$ and water/feedstock mass ratio of 20:1 with 2.0 $\mathrm{MPa}$ initial $\mathrm{N}_{2}$ pressure).

\subsection{Comparison with the relevant studies}

A variety of low value biomass have been investigated as feedstock for the crude bio-oil production via HTL, including agricultural and forest residues, food-processing waste, animal manure and municipal solid waste (MSW), etc. Our present study was a first attempt to produce the crude bio-oil from SCG, therefore, it is necessary to compare the results obtained with other studies in this field to evaluate the feasibility and the promise of SCG liquefaction. It is important to point out that this comparison is a generally qualitative comparison, as each feedstock was liquefied under different conditions as reported in the literature. We made our best effort to select the cases in which liquefaction conditions were close to our experimental conditions (water as a medium and in nitrogen atmosphere without any catalysts application).

Table 3 provides the properties of bio-oils derived from the HTL of SCG and other representative biomass. In general, the crude bio-oil derived from SCG liquefaction has a much higher yield (47.28\%) and a slightly lower $\mathrm{HHV}\left(31.0 \mathrm{MJ} \cdot \mathrm{kg}^{-1}\right)$, compared to the crude bio-oils derived from lignocellulose-based biomass such as Jack pine wood sawdust, corn stalk, tea waste, and pulp/paper sludge. However, the reaction condition employed in the HTL of SCG is milder or more favorable than the HTL of lignocellulose biomass, for example, a lower temperature and a shorter retention time. In terms of the composition, the crude bio-oil from SCG is composed of long-chain carboxylic acids. No phenolic compounds were detected, which is very different from the crude bio-oils generated from other lignocellulose feedstock. This may be attributed to a low lignin content in the SCG and various liquefaction conditions. Microalgae and oilseeds demonstrated themselves as excellent feedstocks for the HTL process. As shown in Table 3, microalgae, Nannochloropsis $s p$, was liquefied at $350^{\circ} \mathrm{C}$, giving a fairly high yield of the crude bio-oil (43.0 \%) and a HHV of $39.0 \mathrm{MJ} \cdot \mathrm{kg}^{-1}$. HTL of Litsea cubeba seed achieved an even 
higher yield of the oil product (56.9\%) with a HHV value of $40.8 \mathrm{MJ} \cdot \mathrm{kg}^{-1}$, both of which are much higher than those of the crude bio-oil from SCG liquefaction (oil yield of $47.3 \%$, HHV of $31.0 \mathrm{MJ} \cdot \mathrm{kg}^{-1}$ ). This is not surprising because Nannochloropsis sp, and Litsea cubeba seed contains high contents of lipid (28.0\% and $41.0 \%$, respectively) and protein (52.0\% and $35.0 \%$, respectively), which was believed to be able to enhance the crude bio-oil yield in the HTL processes [44-48,51,52]. However, high lipid content materials can be converted into biodiesel comparable to petro-diesel, through a process known as transesterification, less costly than HTL. More concerning, the cultivation of algae and Litsea cubeba requires additional energy inputs. On the contrary, SCG, a waste stream does not require extra energy for the feedstock plantation. The above comparison suggests that SCG can become a promising feedstock for HTL. The yield of crude bio-oil from HTL of SCG is much higher than those of lignocellulose feedstock and its HHV is comparable or slightly lower than that of lignocellulose feedstock. However, SCG biooil is still not competitive to the bio-oils derived from the protein/lipid rich biomass such as microalgae and oilseeds in terms of yield and higher heating value.

\section{[Here] Table 3 Properties of crude bio-oils derived from HTL of SCG and other biomass.}

Alternatively, other processing methods such as lipid extraction and fast pyrolysis have also been exploited to utilize SCG for the liquid fuel production. Thus, it is worthwhile to compare the HTL with other pathways. Table 4 presents the properties of the oil derived from SCG by using HTL, fast pyrolysis and solvent extraction, respectively. Compared to the fast pyrolysis oil, the crude bio-oil obtained from the HTL process has a higher content of carbon and hydrogen while a lower content of water and oxygen, consequently an oil product with a higher HHV. It is concluded that the HTL can provide a larger capability of water and oxygen removal and a more hydrophobic bio-oil product with a lower acidity than fast pyrolysis, while the fast pyrolysis is able to obtain a higher yield of the crude bio-oil (54.9 \%) than HTL (47.3\%). However, achieving such a high oil yield requires a high temperature $\left(>500{ }^{\circ} \mathrm{C}\right)$. More importantly, HTL is advantageous over the fast pyrolysis in that it can utilize feedstock with any moisture level without any pre-drying processes. Compared to the coffee oil extraction the for biodiesel production with a yield of $15.0 \%$, HTL produced a higher yield of oil product. It not only can "extract" lipid content but also generate oil from other components such as carbohydrate and 
465 466

467

468 469

470

471

472

473

474

475

476

477

478

479

480

481

482

483

484

485

486

487

488

489

490

491

492

493

494

protein in SCG. The comparison indicates HTL to be a more suitable technology to produce liquid fuels from SCG.

[Here] Table 4 Properties of oil products derived from SCG.

\section{Conclusions}

HTL was identified to be a promising technology for the crude bio-oil production from SCG. The preferable liquefaction conditions were determined as: the reaction temperature of $275^{\circ} \mathrm{C}$, retention time of $10 \mathrm{~min}$ and water/feedstock mass ratio of 20:1. Under such reaction conditions, the highest crude bio-oil yield of $47.3 \%$ mass fraction was achieved with a higher heating value (HHV) of $31.0 \mathrm{MJ} \cdot \mathrm{kg}^{-1}$, much higher than that of SCG which was only $20.2 \mathrm{MJ} \cdot \mathrm{kg}^{-1}$. The energy recovery percentage was $72.6 \%$. This work is an attempt to utilize the waste stream from the coffee industries for the bio-oil production via HTL. More research is needed and recommended, including the liquefaction process conducted in other solvents or co-solvents, and the investigation on the effects of catalysts on the yield and composition of the resulting bio-oil.

\section{Acknowledgements}

The authors would like to acknowledge the financial support provided by Growing Forward 2 program, Nova Scotia Department of Agriculture, the NSERC Discovery and BioFuelNet grants. One of the authors (L.Y.) is grateful for the facilities and support offered by Institute for Chemicals and Fuels from Alternative Resources (ICFAR) during her visiting studies at Western University.

\section{References:}

[1] Nigam PS, Singh A. Production in liquid biofuels from renewable resources. Prog. Energy Combust. Sci. 2011; 37(1): 52-68.

[2] Peterson AA, Vogel F, Lachance RP, Fröling M, Antal M J, Tester JW. Thermochemical biofuel production in hydrothermal media: A review of sub- and supercritical water technologies. Energy Environ. Sci. 2008; 1(1): 32-65. 
[3] Minowa T, Kondo T, Sudirjo ST. Thermochemical liquefaction of Indonesian biomass residues. Biomass Bioenergy 1998; 14(5): 517-524.

[4] Appell HR, Fu YC, Friedman S, Yavorsky PM, Wender I. Converting organic wastes to oil. Agric. Eng. 1972; 17 -19.

[5] Savage PE, Levine RB, Huelsman CM. Hydrothermal Processing of Biomass. In: Crocker M, editor. Thermochemical Conversion of Biomass to Liquid Fuels and Chemicals. Cambridge: Royal Society of Chemistry; 2010. p. 192-221.

[6] Panisko E, Wietsma T, Lemmon T, Albrecht K, Howe D. Characterization of the aqueous fractions from hydrotreatment and hydrothermal liquefaction of lignocellulosic feedstocks. Biomass Bioenergy 2015; 74: 162-171.

[7] Wang, BF, Huang, YR, Zhang JJ. Hydrothermal liquefaction of lignite, wheat straw and plastic waste in sub-critical water for oil: Product distribution. J. Anal. Appl. Pyrolysis. 2014; 110: 382-389.

[8] Azadi P, Farnood R. Review of heterogeneous catalysts for sub- and supercritical water gasification of biomass and wastes. Int. J. Hydrog. Energy, 2011; 36(16):9529-41.

[9] Luo J, Fang Z, Smith RL. Ultrasound-enhanced conversion of biomass to biofuels. Prog. Energy Combust. Sci. 2014; 41:56-93.

[10] Theegala CS, Midgett JS. Hydrothermal liquefaction of separate dairy manure for production of bio-oils with simultaneous waste treatment. Bioresour. Technol. 2012; 107:456-63. [11] Mussatto SI, Machado EMS, Martins S, Teixeira JA. Production, composition, and application of coffee and its industrial residues. Food Bioprocess Technol. 2011; 4(5):661-72.

[12] Kondamudi N, Mohapatra SK, Misra M. Spent coffee grounds as a versatile source of green energy. J. Agric. Food Chem. 2008; 56(24): 11757-60.

[13] International Coffee Organization, Exporting countries: total production. Available at: http://www.ico.org/prices/po.htm. pdf [accessed 30.06.15].

[14] Liu K, Price GW. Evaluation of three composting systems for the management of spent coffee grounds. Bioresour. Technol. 2011; 102(17): 7966-74.

[15] Sprules RK. inventor; Sprules; Rodney K., assignee. Coffee- Based solid fuel composition. United States Patent US 5910454. 1999 June 8. 
524 [16] Limousy L, Jeguirim M, Dutournie P, Kraiem N, Lajili M, Said R. Gaseous products and

525 particulate matter emissions of biomass residential boiler fired with spent coffee grounds 526 pellets. Fuel 2013; 107: 323-329.

527 [17] Mussatto S, Machado E, Carneiro L, Teixeira JA. Sugars metabolism and ethanol

$528 \quad$ production by different yeast strains from coffee industry wastes hydrolysates. Appl. Energy $5292012 ; 92: 763-768$.

530 [18] Romeiro GA, Salgado EC, Silva RV, Figueiredo MK, Pinto PA, Damasceno RN. A study of 531 pyrolysis from soluble coffee ground using low temperature conversion (LTC) process. J.

532

533

534

535

536

537

538

539

540

541

542

543

544

545

546

547

548

549

550

551

552

553

554 Anal. Appl. Pyrolysis 2012; 93: 47-51.

[19] Bok JP, Choi HS, Choi YS, Park HC, Kim SJ. Fast pyrolysis of coffee grounds:

Characteristics of product yields and biocrude oil quality. Energy 2012; 47(1): 17-24.

[20] Li XF, Strezov V, Kan T. Energy recovery potential analysis of spent coffee grounds pyrolysis products. J. Anal. Appl. Pyrolysis 2014; 110: 79-87.

[21] Behrendt F, Neubauer Y, Oevermann M, Wilmes B, Zobel N. Direct Liquefaction of Biomass. Chem. Eng. Technol. 2008; 31(5): 667-677.

[22] Toor SS, Rosendahl L, Rudolf A. Hydrothermal liquefaction of biomass: A review of subcritical water technologies. Energy 2011; 36(5): 2328-2342.

[23] Elliott DC. Historical Development in Hydroprocessing Bio-oils. Energy Fuels 2007; 21(3):1792-1815.

[24] Demirbas A. Competitive liquid biofuels from biomass. Appl. Energy 2011; 88(1): 17-28.

[25] Huber G.W., Iborra S., Corma A. Synthesis of transportation fuels from biomass: chemistry, catalysts, and engineering. Chem. Rev. 2006; 106:4044-98.

[26] Goudriaan F, Peferoen DGR. Liquid fuels from biomass via a hydrothermal process. Chem. Eng. Sci. 1990; 45(8): 2729-34.

[27] Cheng SN, D'cruz I, Wang MC, Leitch M, Xu CB. Highly efficient liquefaction of woody biomass in hot-compressed alcohol-water co-solvents. Energy Fuels 2010; 24(9): 4659-67.

[28] Wang Y, Wang H, Lin HF, Zheng Y, Zhao JS, Pelletier A, Li KC. Effects of solvents and catalysts in liquefaction of pinewood sawdust for the production of bio-oils. Biomass Bioenergy 2013; 59:158-167.

[29] Xu CB, Lad N. Production of heavy oils with high caloric values by direct liquefaction of woody biomass in sub/near-critical water. Energy Fuels 2008; 22(1): 635-642. 
[30] Zhu YH, Biddy MJ, Jones SB, Elliott DC, Schmidt AJ. Techno-economic analysis of liquid fuel production from woody biomass via hydrothermal liquefaction (HTL) and upgrading. Appl. Energy 2014; 129:348-394.

[31] Zhu Z, Rosendahl L, Toor SS, Yu DH, Chen GY. Hydrothermal liquefaction of barley straw to bio-crude oil: Effects of reaction temperature and aqueous phase recirculation. Appl. Energy 2015; 137: 183-192.

[32] Peng W, Wu C, Wu S, Wu Y, Gao J. The effects of reaction atmosphere on composition, oxygen distribution, and heating value of products from the hydrothermal liquefaction of corn stalk. Energy Sources, Part A: Recovery, Util. Environ. Eff. 2014; 36(4): 347-356.

[33] Gan J, Yuan WQ. Operating condition optimization of corncob hydrothermal conversion for bio-oil production. Appl. Energy 2013; 103:350-357.

[34] Liu Y, Yuan XZ, Huang HJ, Wang XL, Wang H, Zeng GM. Thermochemical liquefaction of rice husk for bio-oil production in mixed solvent (ethanol-water). Fuel Process. Technol. 2013; 112: 93-99.

[35] Cantrell K, Ro K, Mahajan D, Anjom M, Hunt PG. Role of thermochemical conversion in livestock waste-to-energy treatments: obstacles and opportunities. Ind. Eng. Chem. Res. 2007; 46(26): 8918-8927.

[36] Xiu SN, Shahbazi A, Shirley V, Cheng D. Hydrothermal pyrolysis of swine manure to biooil: Effects of operating parameters on products yield and characterization of bio-oil. J. Anal. Appl. Pyrolysis 2010; 88(1): 73-79.

[37] Yin SD, Dolan R, Harris M, Tan ZC. Subcritical hydrothermal liquefaction of cattle manure to bio-oil: Effects of conversion parameters on bio-oil yield and characterization of bio-oil. Bioresour. Technol. 2010; 101(10): 3657-3664.

[38] Minowa, T., Murakami M, Dote Y, Ogi T, Yokoyama SY. Oil production from garbage by thermochemical liquefaction. Biomass Bioenergy 1995; 8(2), 117-120.

[39] Hammerschmidt A, Boukis N, Hauer E, Galla U, Dinjus E, Hitzmann B, et al. Catalytic conversion of waste biomass by hydrothermal treatment. Fuel 2011; 90(2): 555-562.

[40] Xu C, Lancaster J. Conversion of secondary pulp/paper sludge to bio-oils by direct liquefaction in hot compressed or sub- and near-critical water. Water Res. 2008; 42(6-7): 1571-82. 
585

586

587

588

589

590

591

592

593

594

595

596

597

598

599

600

601

602

603

604

605

606

607

608

609

610

611

612

613

614

[41] Brown TM, Duan PG, Savage PE. Hydrothermal liquefaction and gasification of Nannochloropsis sp. Energy Fuels 2010; 24(6): 3639-3646.

[42] Valdez PJ, Nelson MC, Wang HY, Lin XX, Savage PE. Hydrothermal liquefaction of Nannochloropsis sp: Systematic study of process variables and analysis of the product fractions. Biomass Bioenergy 2012; 46: 317-331.

[43] Jena U, Das KC. Comparative evaluation of thermochemical liquefaction and pyrolysis for bio-oil production from microalgae. Energy Fuels 2011; 25(11): 5472-5482.

[44] Biller P, Ross AB. Potential yields and properties of oil from the hydrothermal liquefaction of microalgae with different biochemical content. Bioresour. Technol. 2011; 102(1): 215-25.

[45] Biller P, Riley R, Ross AB. Catalytic hydrothermal processing of microalgae:

Decomposition and upgrading of lipids. Bioresour. Technol. 2011; 102(7): 4841-48.

[46] Barreiro DL, Gómez BR, Hornung U, Kruse A, Prins W. Hydrothermal liquefaction of microalgae in a continuous stirred-tank reactor. Energy Fuels 2015; 29(10): 6422-32.

[47] Barreiro DL, Samorì C, Terranella G, Hornung U, Kruse A, Prins W. Assessing microalgae biorefinery routes for the production of biofuels via hydrothermal liquefaction. Bioresour. Technol. 2014; 174: 256-65.

[48] Barreiro DL, Zamalloa C, Boon N, Vyverman W, Ronsse F, Brilman W, Prins W. Influence of strain-specific parameters on hydrothermal liquefaction of microalgae. Bioresour. Technol. 2013; 146: 463-71.

[49] Akhtar J, Amin NAS. A review on process conditions for optimum bio-oil yield in hydrothermal liquefaction of biomass. Renew. Sustain. Energy Rev. 2011; 15(3): 1615-1624.

[50] Demirbas A. Thermochemical conversion of biomass to liquid products in the aqueous medium. Energy Sources 2005; 27(13): 1235-43.

[51]Wang F, Chang ZF, Duan PG, Yan WH, Xu YP, Zhang L, et al. Hydrothermal liquefaction of Litea cubeba seed to produce bio-oils. Biorecour. Tehcnol. 2013; 149: 509-515.

[52] Teri G, Luo LG, Savage PE. Hydrothermal treatment of protein, polysaccharide, and lipids alone and in mixtures. Energy Fuels 2014; 28(12): 7501-7509.

[53] Ballesteros LF, Teixeira JA, Mussatto SI. Chemical, functional, and structural properties of spent coffee grounds and coffee silverskin. Food Bioprocess Technol. 2014; 7(12): 34933503. 
615 [54] Sasaki M, Adschiri T, Arai K. Production of cellulose II from native cellulose by near and 616 supercritical water solubilization. J. Agric. Food Chem. 2003; 51(18): 5376-81.

617 [55] Qu YX, Wei XM, Zhong CL. Experimental study on the direct liquefaction of 618 Cunninghamia lanceolata in water. Energy 2003; 28(7), 597-606.

619 [56] El-Rub AZ, Bramer EA, Brem G. Review of catalysts for tar elimination in biomass 620 gasification processes. Ind. Eng. Chem. Res. 2004; 43(22): 6911-6919.

621 [57] Yu G, Zhang Y, Schideman L, Funk TL, Wang Z. Hydrothermal liquefaction of low lipid 622 content microalgae into bio-crude oil. Trans. ASABE 2011; 54(1): 239-246.

623

\section{List of Tables:}

625 626

627 628 629

630

Table 1. Elemental analyses of SCG and crude bio-oil under the reaction condition of $275^{\circ} \mathrm{C}, 10$ min, 20:1 water/feedstock mass ratio with 2.0 $\mathrm{MPa}$ initial $\mathrm{N}_{2}$ pressure.

Table 2. Major compounds in the crude bio-oil derived from SCG liquefaction (temperature of $275^{\circ} \mathrm{C}$, retention time of $10 \mathrm{~min}$ and water/feedstock mass ratio of $20: 1$ with $2.0 \mathrm{MPa}$ initial $\mathrm{N}_{2}$ pressure).

Table 3. Properties of crude bio-oils derived from HTL of SCG and other biomass.

Table 4. Properties of oil products derived from SCG.

Table 1. Elemental analyses of SCG and crude bio-oil under the reaction condition of $275^{\circ} \mathrm{C}, 10$ min, 20:1 water/feedstock mass ratio with 2.0 $\mathrm{MPa}$ initial $\mathrm{N}_{2}$ pressure.

\begin{tabular}{|c|c|c|c|c|c|c|c|c|}
\hline \multirow[t]{2}{*}{ Sample } & \multicolumn{4}{|c|}{ Elemental compositions, \% } & \multirow{2}{*}{$\begin{array}{l}\mathrm{HHV}^{\mathrm{b}} \\
\left(\mathrm{MJ} \cdot \mathrm{kg}^{-\mathbf{1}}\right)\end{array}$} & \multirow{2}{*}{$\begin{array}{l}\mathrm{H} / \mathrm{C} \\
\text { (molar } \\
\text { ratio) }\end{array}$} & \multirow{2}{*}{$\begin{array}{l}\mathrm{O} / \mathrm{C} \\
\text { (molar } \\
\text { ratio) }\end{array}$} & \multirow{2}{*}{$\begin{array}{l}\text { Energy } \\
\text { Recovery }^{\mathrm{c}} \\
(\%)\end{array}$} \\
\hline & $\mathbf{C}$ & $\mathbf{H}$ & $\mathbf{N}$ & $\mathbf{O}^{\mathbf{a}}$ & & & & \\
\hline $\begin{array}{l}\text { Spent coffee } \\
\text { grounds }^{\mathrm{d}}\end{array}$ & 50.4 & 7.2 & 2.1 & 40.3 & 20.2 & 1.7 & 0.6 & \\
\hline $\begin{array}{l}\text { Crude bio-oil }(\mathrm{W} / \mathrm{F} \\
\text { mass ratio }=1: 20 ; \\
\left.275^{\circ} \mathrm{C} ; 10 \mathrm{~min}\right)\end{array}$ & 71.2 & 7.1 & 3.0 & 18.7 & 31.0 & 1.2 & 0.2 & 72.6 \\
\hline
\end{tabular}


637 a by mass difference; ${ }^{\mathrm{b}}$ Higher heating value calculated by the Dulong formula: $\mathrm{HHV}\left(\mathrm{MJ} \cdot \mathrm{kg}^{-1}\right)=0.3383 \mathrm{C}$

$638+1.442(\mathrm{H}-(\mathrm{O} / 8)) ;{ }^{\mathrm{c}}$ Energy recovery $(\%)=\frac{\mathrm{HHV} \text { of crude bio-oil } \times \text { mass of crude bio-oil }}{\mathrm{HHV} \text { of SCG } \times \text { mass of SCG }} \times 100 .{ }^{\mathrm{d}}$ On a dry basis.

639

640

641

642

643

644

645

646 Table 2. Major compounds in the crude bio-oil derived from SCG liquefaction (temperature of

$647275^{\circ} \mathrm{C}$, retention time of $10 \mathrm{~min}$ and water/feedstock mass ratio of 20:1 with $2.0 \mathrm{MPa}$ initial $\mathrm{N}_{2}$

648 pressure).

\begin{tabular}{|c|c|c|c|c|}
\hline Peak & $\begin{array}{l}\text { RT } \\
\text { (min) }\end{array}$ & Compound name & Formula & $\begin{array}{l}\text { Area } \\
\%\end{array}$ \\
\hline 1 & 11.5066 & n-Hexadecanoic acid & $\mathrm{C}_{16} \mathrm{H}_{32} \mathrm{O}_{2}$ & 48.15 \\
\hline 2 & 12.4227 & Octadecanoic acid & $\mathrm{C}_{18} \mathrm{H}_{36} \mathrm{O}_{2}$ & 15.46 \\
\hline 3 & 12.4863 & 9,12-Octadecadienoic acid (Z,Z)- & $\mathrm{C}_{18} \mathrm{H}_{32} \mathrm{O}_{2}$ & 34.43 \\
\hline 4 & 13.2816 & Eicosanoic acid & $\mathrm{C}_{20} \mathrm{H}_{40} \mathrm{O}_{2}$ & 1.58 \\
\hline 5 & 15.2665 & Octanoic acid, heptadecyl ester & $\mathrm{C}_{25} \mathrm{H}_{50} \mathrm{O}_{2}$ & 0.38 \\
\hline Total area \% & & & & 100.0 \\
\hline
\end{tabular}

649

650

651

652

653

654 
Table 3. Properties of crude bio-oils derived from HTL of SCG and other biomass.

\begin{tabular}{|c|c|c|c|c|c|c|c|c|c|}
\hline Feedstock & $\begin{array}{l}\text { Liquefaction } \\
\text { conditions }\end{array}$ & $\mathrm{C} \%$ & $\mathbf{H \%}$ & O\% & N\% & $\begin{array}{l}\text { HHV } \\
\left(\mathbf{M J} \cdot \mathbf{k g}^{-1}\right)\end{array}$ & $\begin{array}{l}\text { Max Oil } \\
\text { yield } \\
\text { (\% mass } \\
\text { fraction) }\end{array}$ & $\begin{array}{l}\text { Main product } \\
\text { distribution from } \\
\text { GC-MS analysis }\end{array}$ & Reference \\
\hline SCG & $\begin{array}{l}275^{\circ} \mathrm{C}, 10 \\
\min , \mathrm{N}_{2}\end{array}$ & 71.2 & 7.12 & 18.7 & 2.95 & 31.0 & 47.3 & $\begin{array}{l}\text { Long chain } \\
\text { carboxylic acids }\end{array}$ & In this study \\
\hline $\begin{array}{l}\text { Jack pine } \\
\text { wood sawdust }\end{array}$ & $\begin{array}{l}340^{\circ} \mathrm{C}, 30 \\
\min , \mathrm{N}_{2}\end{array}$ & 76.3 & 6.7 & 17.1 & 0.0 & 32.3 & 36.0 & $\begin{array}{l}\text { Phenolic } \\
\text { compounds, } \\
\text { carboxylic } \\
\text { acids/esters }\end{array}$ & [29] \\
\hline Tea waste & $\begin{array}{l}377^{\circ} \mathrm{C}, 25 \\
\min ,-{ }^{\mathrm{a}}\end{array}$ & 71.6 & 5.6 & 22.8 & 0.0 & 33.6 & 22.6 & ( & [50] \\
\hline Corn stalk & $\begin{array}{l}380^{\circ} \mathrm{C}, 30 \\
\min , \mathrm{N}_{2}\end{array}$ & 77.8 & 6.9 & 14.9 & 0.0 & 33.5 & 36.0 & - & [32] \\
\hline $\begin{array}{l}\text { Swine } \\
\text { manure }\end{array}$ & $\begin{array}{l}340^{\circ} \mathrm{C}, 15 \\
\min , \mathrm{N}_{2}\end{array}$ & 72.6 & 9.76 & 13.2 & 4.5 & 36.1 & 24.2 & $\begin{array}{l}\text { Aromatic } \\
\text { hydrocarbons, } \\
\text { phenol, carboxylic } \\
\text { acids, alkenes, } \\
\text { nitrogenous } \\
\text { compounds }\end{array}$ & [36] \\
\hline $\begin{array}{l}\text { Pulp/paper } \\
\text { sludge } \\
\text { powder }\end{array}$ & $\begin{array}{l}280^{\circ} \mathrm{C}, 60 \\
\min , \mathrm{N}_{2}\end{array}$ & 75.5 & 8.5 & 12.1 & 3.9 & 35.4 & 20.3 & $\begin{array}{l}\text { Carboxylic acids, } \\
\text { heterocyclic } \\
\text { nitrogen } \\
\text { compounds, } \\
\text { phenolic compounds }\end{array}$ & {$[40]$} \\
\hline $\begin{array}{l}\text { Microalgae } \\
\text { (Nannochloro } \\
\text { psis sp.) }\end{array}$ & $\begin{array}{l}350^{\circ} \mathrm{C}, 60 \\
\min , \mathrm{He}\end{array}$ & 76.0 & 10.3 & 9.0 & 3.9 & 39.0 & 43.0 & $\begin{array}{l}\text { Phenol, N- } \\
\text { containing } \\
\text { compounds, long- } \\
\text { chain fatty acids, } \\
\text { alkanes and alkenes }\end{array}$ & [41] \\
\hline Litsea cubeba & $290^{\circ} \mathrm{C}, 60$ & 76.2 & 11.9 & 10.4 & 3.9 & 40.8 & 56.9 & Toluene, fatty acids & {$[51]$} \\
\hline
\end{tabular}




\begin{tabular}{lcc}
\hline seed & $\min ,-^{a}$ & and their derives \\
\hline 665 & ${ }^{a}$ not detected or provided
\end{tabular}

666

667

668

Table 4 Properties of oil products derived from SCG.

\begin{tabular}{|c|c|c|c|c|c|c|c|c|c|c|}
\hline Oil products from SCG & $\mathrm{C} \%$ & H\% & O\% & N\% & $\mathrm{O} / \mathrm{C}$ & $\begin{array}{l}\text { HHV } \\
\left(\mathbf{M J} \cdot \mathbf{k g}^{-1}\right)\end{array}$ & $\begin{array}{l}\text { Max Oil yield } \\
\text { ( } \% \text { mass } \\
\text { fraction) }\end{array}$ & $\begin{array}{l}\text { Water } \\
\text { content } \\
(\%)\end{array}$ & $\mathrm{pH}$ & Ref. \\
\hline $\begin{array}{l}\text { Crude bio-oil obtained } \\
\text { in this study }\end{array}$ & 71.2 & 7.1 & 18.7 & 3.0 & 0.2 & 31.0 & 47.3 & 2.1 & 4.8 & \multirow{2}{*}{$\begin{array}{l}\text { Current } \\
\text { research } \\
{[19]}\end{array}$} \\
\hline Fast pyrolysis oil & 54.3 & 7.4 & 35.3 & 3.1 & 0.4 & 20.4 & 54.9 & 31.1 & 3.1 & \\
\hline Biodiesel & $\mathrm{-}^{\mathrm{a}}$ & - & - & - & - & - & 15.0 & - & - & {$[12]$} \\
\hline
\end{tabular}




\section{List of Figures:}

Figure 1. Yields of bio-oil, solid residue, WSP, and gas under different retention time (temperature of $300{ }^{\circ} \mathrm{C}$ and water/feedstock mass ratio of 5:1 with $2.0 \mathrm{MPa}$ initial $\mathrm{N}_{2}$ pressure).

Figure 2. Yields of bio-oil, solid residue, WSP, and gas from the liquefaction at various reaction temperatures (retention time of $10 \mathrm{~min}$ and water/feedstock mass ratio of 5:1 with $2.0 \mathrm{MPa}$ initial $\mathrm{N}_{2}$ pressure).

Figure 3. Yields of bio-oil, solid residue, WSP, and gas from the liquefaction with various water/feedstock mass ratios (retention time of $10 \mathrm{~min}$ and temperature of $275{ }^{\circ} \mathrm{C}$ with $2.0 \mathrm{MPa}$ initial $\mathrm{N}_{2}$ pressure).

Figure 4. FTIR spectrum of SCG and the crude bio-oil derived from SCG liquefaction (temperature of $275^{\circ} \mathrm{C}$, reaction time of $10 \mathrm{~min}$ and water/feedstock mass ratio of 20:1 with 2.0 $\mathrm{MPa}$ initial $\mathrm{N}_{2}$ pressure).

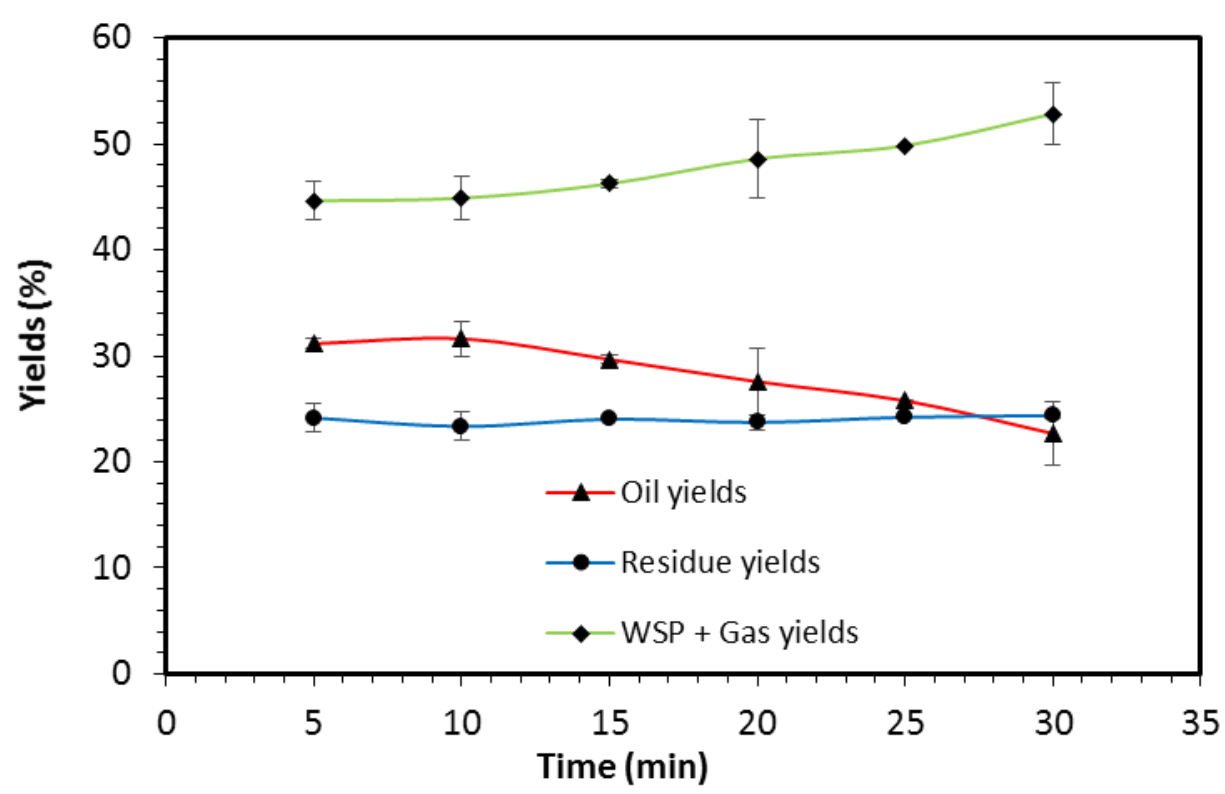

Fig. 1. Yields of bio-oil, solid residue, WSP, and gas under different retention time (temperature of $300{ }^{\circ} \mathrm{C}$ and water/feedstock mass ratio of 5:1 with $2.0 \mathrm{MPa}$ initial $\mathrm{N}_{2}$ pressure). 


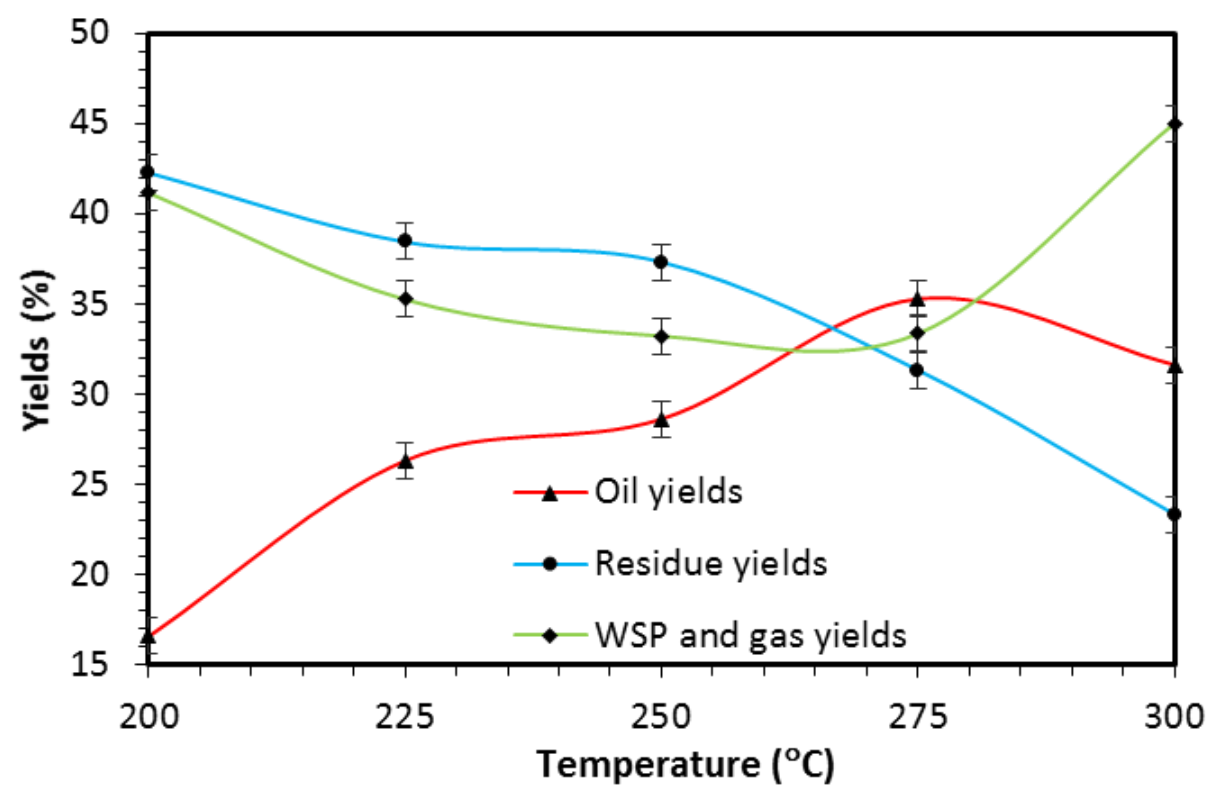

Fig. 2. Yields of bio-oil, solid residue, WSP, and gas from the liquefaction at various reaction temperatures (retention time of $10 \mathrm{~min}$ and water/feedstock mass ratio of 5:1 with $2.0 \mathrm{MPa}$ initial $\mathrm{N}_{2}$ pressure).

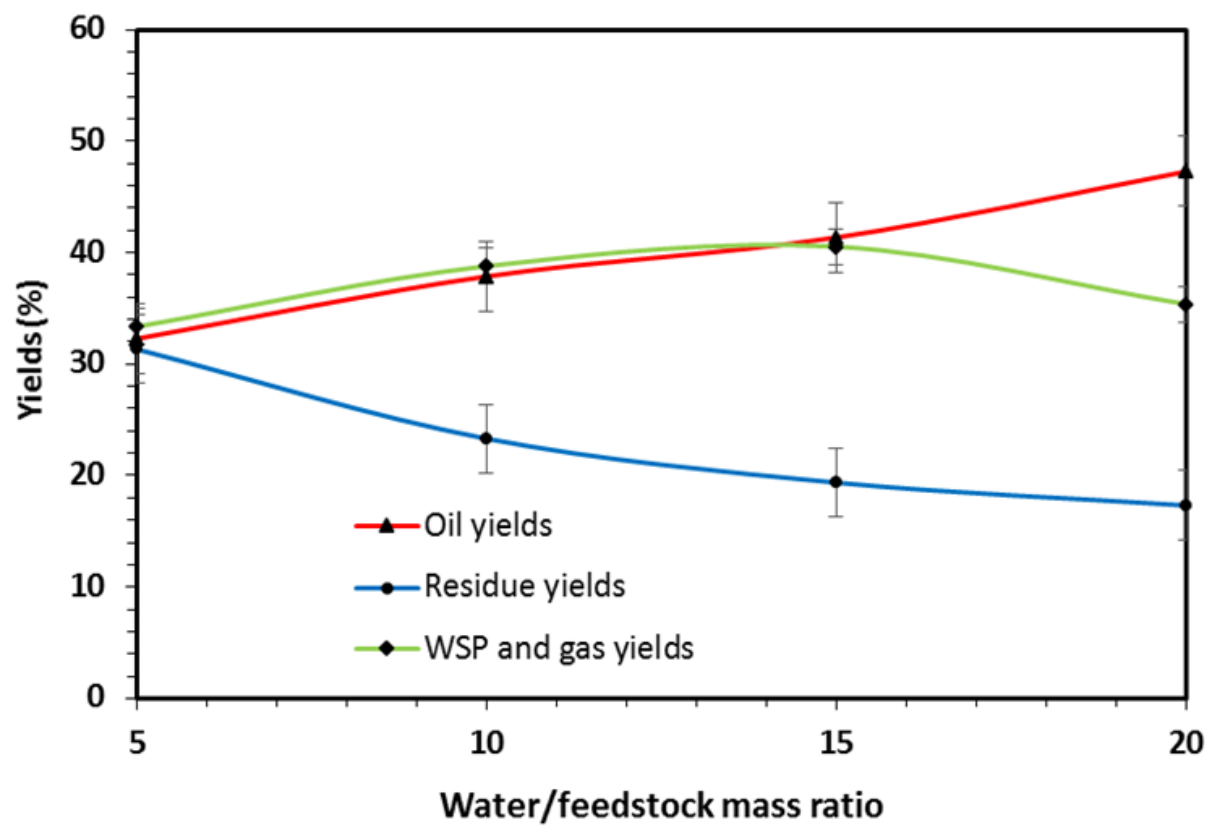

Fig. 3. Yields of bio-oil, solid residue, WSP, and gas from the liquefaction with various water/feedstock mass ratios (retention time of $10 \mathrm{~min}$ and temperature of $275^{\circ} \mathrm{C}$ with $2.0 \mathrm{MPa}$ initial $\mathrm{N}_{2}$ pressure). 


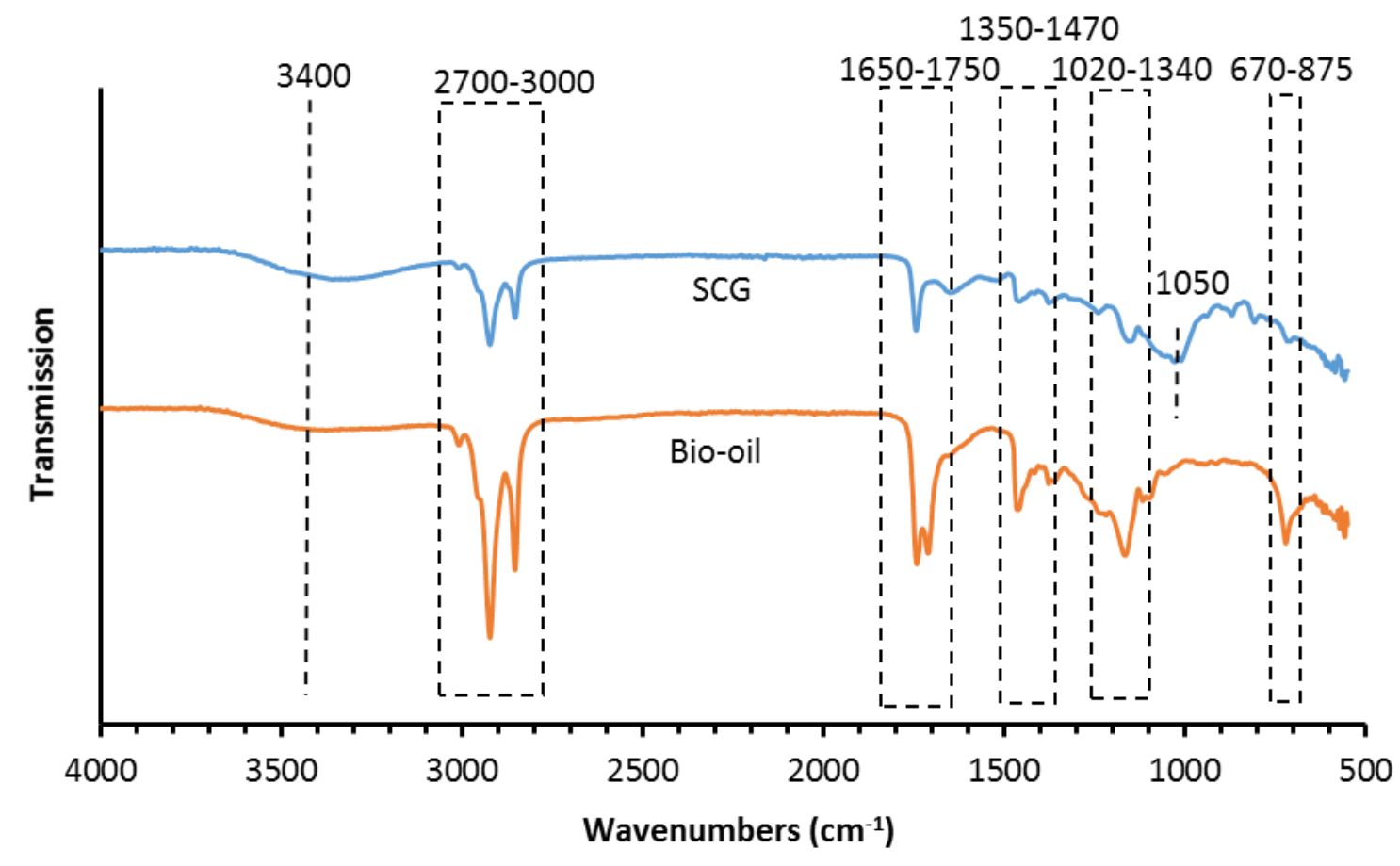

Fig. 4. FTIR spectrum of SCG and the crude bio-oil derived from SCG liquefaction (temperature of $275{ }^{\circ} \mathrm{C}$, retention time of $10 \mathrm{~min}$ and water/feedstock mass ratio of 20:1 with $2.0 \mathrm{MPa}$ initial $\mathrm{N}_{2}$ pressure). 